\title{
GOETHE AS NATURAL PHILOSOPHER
}

(6)

\author{
By Prof. E. N. da C. ANDRADE, F.R.S.
}

G OETHE, the greatest poet that Germany has produced, cwas a dominating intelligence who must claim a prominent place in any history of the human mind, and he devoted a considerable part of his effort to scientif studies. Further, he attached the greatpst imponance to this part of his achieve. ment : said fo Eckermann-who played to him the prit. of Boswell to Johnson-"I do not attach impryince t f my work as a poet, but I do claim to fe athe in hol time in apprehending the truth about clibur". It is not suggested that this represented his balanced judgment-passages can, of course, be quoted to show that he attached the greatest value to his poetry, as when he spoke of it to Eckermann as Mein Eigentliches Glück and regretted the time spent on anything else-but, even if an exaggeration, it is one of many instances showing that for him his science was vastly significant. Yet we must face the fact that while there is in this scientific work of his much that is of the greatest interest, for the light that it throws on a superlative and complex character, there is not much-except, some would contend, in his botanical studies-- that is important for the history of science. Further, it is, alas, precisely where he thought his scientific work most significant, namely, in his attacks on Newton and in his theory of colour, that he most completely fails. Goethe's scientific work may, perhaps, almost stand with Newton's work on theology and chronology-excellent, in many ways, if judged by the standards of the times, very important in the eyes of its producer, but not likely to have been remembered to-day had it been produced by a lesser man.

A great man makes great mistakes, and to understand how Goethe came to fail we must consider what manner of man he was, what his outlook and attitude were. For him Nature was all one, a manifestation of the Godhead, as Sherrington has so well emphasized. He wrote :
"What God would stand outside without concern
Letting creation on his finger turn !
God must inspire all being from within
Nature with Him, Himself with Nature kin.
So that all fabric which his wisdom weaves
Full of his form, full of his spirit lives."*

Characteristic of Goethe was his rapture in open air and light. He was, above all, a man of his eyes : with his keen sight he even derided spectacles, saying, in his attack on instruments as a means of attaining scientific truth, "I have found in life, in the main and on the whole, that artificial means with which we help our senses do not have a good moral influence on man. He who sees through spectacles thinks himself cleverer than he is, for the equilibrium between his outer senses and his innate capacity for judgment is disturbed. $\dagger$ " This delight in things seen stands out

* As the translation, for which I am responsible, of this and other passages here quoted is not absolutely literal, I give, in this case and the others, the original.

$$
\begin{aligned}
& \text { Was wär' ein Gott, der nur von aussen stiesse, } \\
& \text { Im Kreis das All am Finger laufen liesse! } \\
& \text { Inm ziemt's, die Welt im Innern zu bewegen, } \\
& \text { Natur in Sich, Sich in Natur zu hegen, } \\
& \text { So dass was in Ihm lebt und webt und ist, } \\
& \text { Nie Seine Kraft, nie Seinen Geist vermisst. } \\
& \text { "Wanderjahre", Book 1, Chapter } 10 .
\end{aligned}
$$

particularly by contrast with his attitude to things heard: music, although it gave him some pleasure, does not seem to have moved him profoundly, and he said himself "gegen das Auge ist das Ohr ein stummer Sinn"- the ear is a blunted sense compared to the eye. The words schauen, Anschauung dominate his vocabulary. Anschaulichkeit was what he demanded of scientific theory.

For a man of this make-up the methods of physics were repugnant. When he thought of colour he thought, in particular, of the colours that burst upon his eye when he made that journey into Italy which was such a turning point in his life. Colour was a glorious aspect ofiered by Nature, and by art in Italian pictures-blooming trees, far hills, Titian and Caravaggio. He was seeking to find out what colour was, in the spirit of the Middle Ages, rather than how coloured lights behaved, in the spirit of Newton. $\mathrm{He}$ did not believe that dragging light into the laboratory and submitting it to what he thought of as wholly artificial conditions could tell us anything as to the colour of Nature or the nature of colour. "No dark room," he cries :

"Friends, avoid the darkened chamber

Where light's pinched and pushed and trimmed,

Where the miserable chapter

Bow before the falsehood limned.

Sham and superstitious preachers

Of false doctrine we despise :

In the heads of these your teachers

Leave the spectres and the lies."*

He derides the complications of Newton's simple experiment : for the spectre (Gespenst) to appear, he says, the following is necessary: 1, a glass prism; 2 , triangular ; 3 , small ; 4 , a shutter ; 5 , an opening in it; 6, this very small; 7 , in image of the sun, coming into the room; 8 , from a certain distance; 9, falling on the prism in a certain direction; 10 , forming on a board; 11 , that is at a certain distance behind the prism. When he found that if he looked at a white wall through a prism he did not see a broad band of colour, as he had expected on his mistaken reading of Newton, but a white surface with coloured fringes at its boundaries, he was convinced that Newton was wrong, and attacked him in unmeasured terms-for example, "I must," says he of Newton, "quote Reynard the Fox and say 'But I well perceive that lies are needed, and in full measure'."

This is no place to discuss the misunderstandings and false reasoning of which the "Zur Farbenlehre" -his great, in volume, treatise on colour-is full : it is, perhaps, worthy of remark that he called it "Contributions to the Theory of Colour" rather than "The Theory of Colour", feeling, no doubt, that he had not exhausted the subject. He thought of colour as essentially involved with the contrast of light and darkness : the dark background so often helpful for the observation of certain effects was for him an

$$
\begin{aligned}
& \text { * Freunde, flieht die dunkle Kammer, } \\
& \text { Wo man Euch das Licht verzwickt } \\
& \text { Und im kümmerlichsten Jammer } \\
& \text { Sich verschrobnen Bildern bückt. } \\
& \text { Abergläubische Verehrer, } \\
& \text { Gab's die Jahre her genug, } \\
& \text { In den Köpfen Eurer Lehrer } \\
& \text { Lasst Gespenst und Wahn und Trug. }
\end{aligned}
$$


essential. Once more, he summarized his general conclusions elsewhere in poetry :

\author{
"If you fitly can unite \\ Bright and blackness, shade and light, \\ Colour's secrets you may claim. \\ Splitting light unique and holy \\ Hold we for egregious folly, \\ Not to use a harsher name."*
}

His complete misunderstanding of the significance of Newton's work, his senseless attacks on Newton's integrity and authority, his complete opposition to the methods of experimental physics were in general repugnant to the physicists of his time, such as Lichtenberg, and of subsequent times, such as Helmholtz, Tyndall, Arthur Schuster and Wilhelm Ostwald. There are, however, things of value in the "Farbenlehre", as there could scarcely fail to be in a work into which a singularly acute observer had put so much labour. One cause of misunderstanding is that Goethe laid great stress on the colour effects offered by turbid media, such as that provided by a weak suspension of soap in water. The scattered light is bluish, the transmitted light yellowish. Goethe, of course, did not understand the physics of the scattering of light by small particles, which was first cleared up by Tyndall and Rayleigh : furthermore, he would not have accepted the explanation if it had been laid before him, for he held the very methods of mathematical physics in contempt. Neither, however, did the physicists who were Goethe's contemporaries understand the matter-and it is not to be explained on the basis of Newton's optics : if the part of his work which they did understand had not been demonstrably absurd, they might have learnt much from his experiments. Goethe even compared the colour of the sky to the scattering colour of a turbid medium, and so conjectured correctly the cause of the blue of the sky. His explanation, however, was in terms of the simultaneous action of bright and dark, the dark being that of outer space. "If the darkness of infinite space is seen through atmospheric vapours illuminated by daylight; the blue colour appears."

The "Farbenlehre" contains a great number of acute observations of importance in physiological optics, as would be expected from Goethe's whole outlook. Such things as simultaneous contrasts, afterimages, coloured shadows and other subjective effects are fully treated and correctly described. The great physiologist Johannes Müller praised the book and expressed himself as greatly indebted to it : Purkinje likewise thought highly of Goethe's work, and dedicated the second volume of his "Beiträgen zur Kenntnis des Sehens" to the poet. We can, in fact, put full faith in Goethe's statements when they are merely descriptive of subjective phenomena and when he does not enter into explanations.

The "Farbenlehre" was the scientific work on which Goethe himself laid most emphasis, but he spent much time and labour on botanical subjects and on his work on comparative anatomy. To certain principles that governed all his work I have already referred : the immense zest, the view of Nature as a poetic whole, the joy in observation, especially in the open air and in the light of Italy. A word must

\footnotetext{
* Hell und Dunkel, Licht und Schatten Weiss man klüglich sie zu gatten, Ist das Farbenreich gesiegt.

Ist das Farbenreich gesiegt.

Minheit ewigen Lichts zu spalt

Wenn euch Irrtum schon genügt.
}

perhaps be said about the importance which Goethe attached to his conception of the fundamental or typical phenomenon, the Urphänomen. Thus in colour the Urphänomen was the scattering of light in a turbid suspension. In his botanical studies* he likewise sought a fundamental plant, of which all others could be regarded as developments. Among his notes is one "Hypothesis all is leaf and by this simple thing the greatest variety is possible". The thesis of his "Metamorphose der Pflanzen" is that all appendages of the stem are to be regarded as transformed leaves. His theory was not an evolutionary one, in the modern sense, but a comprehensive way of regarding the plant body, a method of interpreting the manifold appearances of vegetable Nature as versions of a fundamental, ideal type. It was not capable of test by systematic study, by observing the actual development of plants, which was, anyhow, not in Goethe's temperament: as he said, Trennen und Zählen lag nicht in meiner Natur. Strangely enough, Schiller put his finger at once on the weakness of the theory regarded from the empirical point of view : after Goethe had expounded his great discovery, the other poet remarked Das ist keine Erfahrung; das ist eine Idee.

Goethe carried his great general ideas into his studies of comparative anatomy. He considers here again that there is an ideal simple type from which the anatomical details of real animals can be considered as deviations or developments. $\mathrm{He}$ was particularly interested in the vertebral column, of which again there was an ideal type. The one discovery with which he was generally credited, that of the intermaxillary bone, was not new. How fantastic some of his speculations were can be illustrated by one example : he states that the tails of animals can be regarded "as an indication of the unending continuity of organic existences" $\dagger$. He invented the word 'morphology', but it has to-day a significance widely different from that attached to it by Goethe.

In his brilliant and penetrating study of Goethe's science + , of which a second edition has recently appeared, Sherrington says "Briefly, what was his 'science'? That light is not resoluble into coloured lights. That the plant is a collection of modified leaves ; that the skull is an adapted piece of backbone -two plausible though superficial conjectures, now, in the fuller light of the cell theory and embryology, set aside ; the 'correlation of parts', a clumsy error he misthought a "law'." It may be that this is a little harsh, especially as regards his botany, but it seems unescapable that the influence of this vast labour, of one of the greatest minds in the history of civilization, on the current of scientific thought is small. There have been attempts to make out that Goethe had general visions of great developments of science that came after him-Helmholtz, though admitting that Goethe's views on the existence of a common type in the animal kingdom had no direct influence on the progress of science, suggests that the famous lines spoken by the Erdgeist in "Faust" - the lines beginning "In Lebensfluten, im

* It is with misgiving that $\mathrm{I}$, with my pitifully weak knowledge of the subject, say anything of Goethe's botany. A difficulty for me is as Agnes Arber has pointed out, that those scholars who have the fullest and most critical knowledge of his writings differ radically in their estimate of this branch of his science. Those interested should consult Dr. Arber's "Goethe's Botany" (Chronica Botanica, Vol. 10, No. 2, 1946), which gives full references.

$\dagger$ Als eine Andeutung der Unendlichkeit organischer Existenzen.

$\ddagger$ "Goethe on Nature and Science" (Cambridge University Press). 
Tatensturm", quoted by Carlyle in Chapter 8 of "Sartor Resartus" - indicate an anticipation of the law of the conservation of energy! Magnus suggests that Goethe's botanical work influenced Jussieu, de Candolle and Robert Brown, a suggestion which I must leave to those more learned than myself in such matters, and, rather half-heartedly, that the foundation of the study of comparative anatomy owes much to Goethe. In some such way it has been suggested that Francis Bacon had a great influence on the work of the early Fellows of the Royal Society, although Bacon's views of the way to set about scientific work were anything but those adopted. It is true, as I have pointed out, that the great physiologists who dealt with colour vision in Goethe's time owed something to him. On the whole, however, it seems to be accepted that, if Goethe had never published anything in science, things would have developed just as they, in fact, did. If Goethe is to be compared to any great figure in the history of science, it must not be to any great modern but rather to Aristotle, whose powers of observation and generalization led him to important advances in the biological sciences while his physics, dominated by philosophical speculation, was not significant. Goethe was a subjective natural philosopher rather than a man of science in the modern sense.

Must we, then, regret that the great man spent so much of his time in fields where his genius produced relatively little of worth? Regrets are, in any case, fruitless, but perhaps they are not even called for. The spectacle of this comprehensive genius attacking such varied problems with such a zest, attempting with such spirit and such confidence to bring a new order into vast fields of knowledge, is an inspiring one. It is well that there shall be seekers after a general light : a stirring up-dust, light and movement-may not be progress, but nevertheless it is occasionally not a bad thing. Be that as it may, in Goethe's activities we see a last attempt-a glorious attempt-to take all culture and all knowledge for one man's province, and we salute it.

\section{6}

\section{RADIOACTIVE TRACERS IN} CHEMISTRY

$\mathrm{T}$ HE scientify programme of this year's anniversarp peting of the Chemical Society was arranged in ollaboration with the Chemistry Division of the Gddernment's Atomic Energy Research Establiskent. During March 28-30 a symposium on "The Chemistry of the Heavy Elements" and on "Radifactive Tracers" took place in Oxford, and on April 1 discussion was held in London on "The Use of Pioactive Tracers in Chemistry". The Oxford mefting has already been reported in Nature of June 18 and 25.

The London discussions were divided in two parts, the morning session being devoted mainly to tracer applications in inorganic and physical chemistry, the afternoon session to organic-chemical and biological problems. After opening remarks by the president of the Chemical Society, Sir Ian Heilbron, Prof. F. A. Paneth took the chair and introduced the subject by a few general remarks on the steadily growing importance of tracer methods in chemistry since the discovery of artificial radioelements and their production on a large scale. The significance of this new research tool for biological investigations was empha. sized by Prof. G. v. Hevesy when he took the chair at the afternoon session.

The question foremost in the minds of many who intend to make use of this technique is, naturally, where and how radioactive tracers can be obtained. It was answered by $H$. Seligman in his report on "The Availability of Radio-Isotopes". He was able to assure the audience that the Atomic Energy Research Establishment at Harwell is now in a position to provide all the tracers of long life which a year or so ago could only be bought from the United States, and those of shorter life as well, which were previously not obtainable by purchase. A novel feature of the Harwell organisation is a kind of information bureau which tries to help those with little experience in the subject by giving advice as to the tracers likely to be most satisfactory in particular research problems and industrial uses. Equally comforting was the news about the prices, which are kept very low--a point which may be sometimes decisive. It is, therefore, unlikely that any research laboratories within reasonable distance from Harwell will ever be hampered in the use of radioactive tracers by lack of the necessary radioactive material ; they might, however, for some while find it more difficult to obtain the equipment of special rooms and high-class modern apparatus, and the stafi trained in the new technique.

The other papers dealt with a variety of researches which had only the one feature in common that in the course of the investigation use had been made of a radioactive tracer; for this very reason they do not lend themselves easily to a summarizing review. all the more so as several of the subjects discussed were of a highly specialized nature. All the papers presented at the meeting will be printed in full in the Journal of the Chemical Society, and those interested in related problems will find in the complete texts a wealth of helpful information; but in this brief report we can scarcely mention more than the subjects of the contributions and give an indication of the main results.

Since the early days of indicator methods, research workers have found them most useful in the study of diffusion problems. K. E. Zimen, M. Hillert and G. Johannson, in Göteborg, have now employed silver-111 and mercury-203 for a determination of the self-diffusion coefficients of silver and mercury; their paper was read by E. Berne. A second paper from Göteborg, by $\mathrm{R}$. Lindner, reported on work done in Prof. Hedvall's laboratory on the selfdiffusion in silver sulphate, lead and zinc oxides, $\mathrm{ZnO} . \mathrm{Fe}_{2} \mathrm{O}_{3}$ and $\mathrm{CaO} . \mathrm{SiO}_{2}$. That such a study of diffusion coefficients by radioactive tracers can be used as a new means for the investigation of condensation processes in solutions was shown by J.S. Anderson and K. Saddington, of the Atomic Energy Research Establishment, Harwell. From the difiusion coefficients of radioactive sodium tungstate, containing tungsten-185 and -187 , it was concluded that with decreasing $p \mathrm{H}$ there is a progressive aggregation of the tungstate ions; above $p \mathrm{H}=9$, the normal tungstate ion exists, whereas over the range $p \mathrm{H}=$ $2 \cdot 3-5$ a condensed ion is predominant.

Prof. J. W. Irvine, jun., reported on researches carried out by him at the Massachusetts Institute of Technology in collaboration with Prof. C. D. Coryell and W. B. Lewis on the "Electron-transfer (Exchange) between Cobaltous- and Cobaltic-amino Complexes". Cobalt-60 was used as tracer in the cobaltous com. 